\title{
TERMINAL STEPS IN THE BIOSYNTHESIS OF HERBICIDINS, NUCLEOSIDE ANTIBIOTICS
}

\author{
Hiroji Yoshikawa, Yo Takiguchi* and Michiya Terao \\ Fermentation Research Laboratories, Sankyo Co., Ltd. \\ 1-12-1, Shibakubo, Tanashi, Tokyo 188, Japan
}

(Received for publication April 3, 1982)

\begin{abstract}
The biosynthetic relationship of the herbicidins produced by Streptomyces saganonensis was studied with blocked mutants by means of a bioconversion method using growing and resting cells. It is proposed that the biosynthetic sequence for herbicidins is; herbicidin $\mathrm{G} \rightarrow$ herbicidin $\mathrm{F} \rightarrow$ herbicidin $\mathrm{A}$. Both herbicidins $\mathrm{A}$ and $\mathrm{F}$ were converted to herbicidin $\mathrm{B}$ by nonenzymatic reactions. Herbicidin $\mathrm{G}$ was also converted to herbicidin $\mathrm{C}$ non-enzymatically.
\end{abstract}

Herbicidins A and B, new nucleoside antibiotics, were found by ARAI et al. in the culture medium of a strain belonging to Streptomyces saganonensis No. 4075 1,2). In the course of fermentation studies for herbicidin production, we isolated two new components, herbicidins $\mathrm{C}$ and $\mathrm{E}$, from the culture me$\operatorname{dium}^{33}$. We also found herbicidins $\mathrm{F}$ and $\mathrm{G}$ in the medium of a mutant which was derived from the parent after treatment with $N$-methyl- $N^{\prime}$-nitro- $N$-nitrosoguanidine during a strain improvement pro$\operatorname{gram}^{4}$. However, the biosynthetic relationship of the herbicidins has not been reported to date. The present paper is concerned with the bioconversion of the herbicidins by the parent strain and its blocked mutants; the conversion of the antibiotics non-enzymatically was also studied to elucidate the terminal steps of the biosynthetic pathway.

\section{Materials and Methods}

Microorganisms

Streptomyces saganonensis M403 and M403R ${ }^{5)}$, and their blocked mutants ${ }^{5)}$ were maintained on YM agar slants. Fermentation products and some properties of these strains are summarized in Table 1.

Isolation of Herbicidins

Herbicidins A, B, C and E were isolated from the culture medium of strain M403R using the procedure reported previously ${ }^{2,3)}$. Herbicidins $\mathrm{F}$ and $\mathrm{G}$ were isolated from the fermentation broth of mutant $\mathrm{m} 17-\mathrm{F}^{4)}$ as described in an earlier publication.

Bioconversion of Herbicidins

Growing-cell System: A vegetative inoculum was grown in $500 \mathrm{ml}$-flasks containing $80 \mathrm{ml}$ of $\mathrm{HC}-2$ medium $^{3)}$. The flasks were inoculated from sporulated cultures and incubated for 45 hours at $27^{\circ} \mathrm{C}$ on a reciprocal shaker at 120 strokes per minute. Fermentation was carried out for 6 days in $500 \mathrm{ml}-$ flasks containing $50 \mathrm{ml}$ of $\mathrm{HC}-4$ medium $^{3)}$. These flasks were inoculated with $5 \%(\mathrm{v} / \mathrm{v})$ vegetative inoculum and incubated at $27^{\circ} \mathrm{C}$ on a reciprocal shaker at 120 strokes per minute. Herbicidins were dissolved in water and added to the flasks after 2 days incubation.

Resting-cell System: In order to prepare washed mycelium without the solid derived from the medium, a soluble medium, HCS-4, was devised. The medium consisted of $20 \mathrm{~g}$ soluble starch, $10 \mathrm{~g}$ glucose, $20 \mathrm{~g}$ Polypepton-S (Daigo Eiyo Kagaku Co., Ltd.), $10 \mathrm{~g} \mathrm{KH}_{2} \mathrm{PO}_{4}, 3 \mathrm{~g} \mathrm{NH} \mathrm{Nl}_{4}, 0.2 \mathrm{~g} \mathrm{MgSO} \cdot 7 \mathrm{H}_{2} \mathrm{O}$

* To whom all correspondences should be addressed.

* Present address: Fermentation Research Laboratories, Sankyo Co., Ltd., 2-58, 1-chome, Hiromachi, Shinagawa-ku, 140 Tokyo, Japan. 
Table 1. Nucleoside antibiotic production by various strains derived from S. saganonensis No. 4075.

\begin{tabular}{|c|c|c|c|c|c|c|c|c|}
\hline \multirow{2}{*}{ Strains } & \multirow{2}{*}{ ara-A } & \multicolumn{6}{|c|}{ Herbicidin } & \\
\hline & & A & $\mathrm{B}$ & $\mathrm{C}$ & $\mathrm{E}$ & $\mathrm{F}$ & G & \\
\hline M403 & + & + & + & + & + & - & - & \\
\hline M403R & + & + & + & + & + & - & - & ara-A $(1 \mathrm{mg} / \mathrm{ml})$ resistant \\
\hline 403R-n30 & + & - & - & - & - & - & - & \\
\hline $\mathrm{m} 17-310$ & - & + & + & - & - & - & - & \\
\hline $\mathrm{m} 17-\mathrm{F}$ & - & - & - & - & - & + & + & \\
\hline $\mathrm{F} 110$ & - & - & - & - & - & + & - & \\
\hline F112 & - & - & - & - & - & + & - & Derived from $\mathrm{m} 17-\mathrm{F}$ \\
\hline F113 & - & - & - & - & - & + & - & \\
\hline A41 & $(+)$ & $(+)$ & $(+)$ & - & - & - & - & Adenine auxotroph \\
\hline
\end{tabular}

-; No accumulation of the compound was detected.

+ ; Accumulation of the compound was detected.

$(+)$; Accumulation of the compound was detected under special conditions. ara-A; 9- $\beta$-D-Arabinofuranosyl adenine.

and $1 \mathrm{~g} \mathrm{ZnSO}_{4} \cdot 7 \mathrm{H}_{2} \mathrm{O}$ per liter. The $\mathrm{pH}$ was adjusted to 6.5 before sterilization. Cultivation was carried out for 2 days at $27^{\circ} \mathrm{C}$ on a reciprocal shaker at 120 strokes per minute in $500 \mathrm{ml}$-flasks containing $80 \mathrm{ml}$ of HCS-4 medium using $5 \%(\mathrm{v} / \mathrm{v})$ vegetative inoculum previously grown in HCS-4 medium. After incubation, the mycelium was harvested by centrifugation $\left(3,000 \mathrm{rpm}, 10\right.$ minutes, $\left.5^{\circ} \mathrm{C}\right)$ and washed twice with sterile potassium phosphate buffer $(0.067 \mathrm{M}, \mathrm{pH}$ 6.8). Bioconversion of the herbicidins was carried out as follows. The washed mycelium (equivalent to $0.3 \mathrm{~g}$ dry weight) was suspended in $10 \mathrm{ml}$ of sterile potassium phosphate buffer $(0.067 \mathrm{M}, \mathrm{pH}$ 6.8) containing $25 \mu \mathrm{g}$ of chloramphenicol $/ \mathrm{ml}$. The suspension was supplemented with various concentrations of herbicidins dissolved in water and incubated at $27^{\circ} \mathrm{C}$ on a reciprocal shaker for 10 hours.

Non-enzymatic Conversion of Herbicidins

Ten milligrams of herbicidins $\mathrm{A}, \mathrm{F}$ or $\mathrm{G}$ were dissolved in $10 \mathrm{ml}$ of $0.1 \mathrm{M}$ potassium phosphate buffer adjusted to $\mathrm{pH} 6.5, \mathrm{pH} 7.5$ and $\mathrm{pH} 8.5$, respectively. Incubations were carried out with shaking at $27^{\circ} \mathrm{C}$ for 30 hours. The concentration of herbicidins in the solution was determined by the assay procedure mentioned below.

\section{Assay Procedure}

Reaction products were determined as follows. The reaction mixtures were centrifuged at 3,000 rpm for 10 minutes. Aliquots of supernatants were examined by means of silica gel thin layer chromatography (Silica Gel 60F $\mathrm{F}_{254}$, E. Merck, Darmstadt, West Germany) using $\mathrm{CHCl}_{3}-\mathrm{MeOH}(7: 3)$, system A, or $n$-hexane - acetone - sodium acetate (75: 75:4.5), system B. Quantitative measurement of the concentration of each herbicidin in a mixture was effected by densitometry at $258 \mathrm{~nm}$ using a Dual-Wavelength TLC Scanner (Model CS-900, Shimadzu Co., Ltd.).

\section{Calculation of Molar Conversion Ratio}

Conversion of compound A to compound B was monitored by determining the molar conversion ratio which was calculated according to the following equation.

$$
\text { Molar conversion ratio }(\%)=\frac{\begin{array}{c}
\text { Increase of compound B } \\
\text { (molar concentration) }
\end{array}}{\begin{array}{c}
\text { Decrease of compound A } \\
\text { (molar concentration) }
\end{array}} \times 100
$$

\section{Results}

Effect of Herbicidins C, E, F and G on the Production of Herbicidin A

In order to establish the biosynthetic relationship of the antibiotics, herbicidins $\mathrm{C}, \mathrm{E}, \mathrm{F}$ or $\mathrm{G}$ was 
added to growing cultures of strain M403R and the mutant, m17-310 (derived from strain M403R). Herbicidins $\mathrm{F}$ and $\mathrm{G}$, added to the medium after 40 hours; were found to increase the titer of herbicidin A (Table 2). The conversion ratio of herbicidin F or $G$ to herbicidin A was about $70 \mathrm{~mole} \%$. By contrast, herbicidin $\mathrm{C}$ or $\mathrm{E}$ did not influence the final yield of herbicidin A (Table 2). Strain A41, an adenine auxotroph, grown in HC-4 medium containing adenine, did not produce any herbicidins.

Table 2. Effect of herbicidins C, E, F, and $\mathrm{G}$ on the production of herbicidin $\mathrm{A}$ in a growing culture of strain M403R and m17-310.

\begin{tabular}{|c|c|c|c|c|c|}
\hline \multirow[b]{2}{*}{ Strain } & \multirow{2}{*}{\multicolumn{2}{|c|}{$\begin{array}{l}\text { Additives } \\
(\mu \mathrm{g} / \mathrm{ml})\end{array}$}} & \multicolumn{2}{|c|}{$\begin{array}{c}\text { Potency after } \\
\text { 70-hour incubation }\end{array}$} & \multirow{2}{*}{$\begin{array}{l}\text { Ratio of } \\
\text { biocon- } \\
\text { version } \\
(\text { mole } \%)\end{array}$} \\
\hline & & & $\begin{array}{c}\text { Herbi- } \\
\text { cidin A } \\
\text { produced } \\
(\mu \mathrm{g} / \mathrm{ml})\end{array}$ & $\begin{array}{c}\text { Residual } \\
\text { additives } \\
(\mu \mathrm{g} / \mathrm{ml})\end{array}$ & \\
\hline \multirow{5}{*}{ M403R } & $\mathrm{Nc}$ & & 820 & & \\
\hline & C & 500 & 800 & 470 & 0 \\
\hline & $\mathrm{E}$ & 500 & 800 & 480 & 0 \\
\hline & $\mathrm{F}$ & 1,000 & 1,460 & 150 & 73 \\
\hline & G & 1,000 & 1,480 & 100 & 71 \\
\hline \multirow{5}{*}{$\mathrm{m} 17-310$} & $\mathrm{Nc}$ & & 1,740 & & \\
\hline & C & 500 & 1,800 & 450 & 0 \\
\hline & $\mathrm{E}$ & 500 & 1,700 & 510 & 0 \\
\hline & $\mathrm{F}$ & 1,000 & 2,440 & 100 & 76 \\
\hline & $\mathrm{G}$ & 1,000 & 2,340 & 150 & 67 \\
\hline
\end{tabular}

However, the strain did produce herbicidin A both in growing and resting cultures when herbicidin $\mathrm{F}$ was added (Table 3 ).

Table 3. Effect of herbicidin $\mathbf{F}$ on the production of herbicidin A by strain A41, adenine auxotroph.

\begin{tabular}{ll|rrrc}
\hline & \multirow{2}{*}{$\begin{array}{c}\text { Additives } \\
(\mu \mathrm{g} / \mathrm{ml})\end{array}$} & \multicolumn{2}{|c}{$\begin{array}{c}\text { Potency }(\mu \mathrm{g} / \mathrm{ml}) \text { after } \\
70 \text {-hour incubation }\end{array}$} & $\begin{array}{c}\text { Ratio of } \\
\text { biocon- } \\
\text { version } \\
\text { (mole } \%)\end{array}$ \\
\cline { 3 - 6 } & A & B & F & 0 & \\
\hline I & None & 0 & 0 & 0 & 71 \\
\hline & F 1,000 & 390 & 0 & 470 & \\
\hline II & None & 0 & 0 & 0 & \\
& F 1,000 & 270 & 100 & 420 & 61 \\
\hline
\end{tabular}

I; Supplemented fermentation by growing cultures.

II; Resting cell system.

Effect of Herbicidins on the Production of Herbicidins F and $\mathrm{G}$

To elucidate the biosynthetic relationship of herbicidins F and G, herbicidins A, C, E, F or G was added to a growing culture of the mutant $\mathrm{m} 17-\mathrm{F}$, which was derived from strain M403. As shown in Table 1, herbicidins $\mathrm{F}$ and $\mathrm{G}$ but not $\mathrm{A}$ are synthesized by this strain. Addition of herbicidin $\mathrm{G}$ to the growing culture increased the titer of herbicidin F, however, herbicidins A, C, E and F did not influence the production of herbicidins $\mathrm{F}$ and $\mathrm{G}$ (Table 4). The conversion ratio of herbicidin $\mathrm{G}$ to $\mathrm{F}$ was about 20 mole \%, which was much lower than the conversion of herbicidin $\mathrm{F}$ to $\mathrm{A}$. In order to examine the effect of herbicidin $\mathrm{G}$ accumulation on the low conversion ratio of herbicidin $\mathrm{G}$ to $\mathrm{F}$ in growing cultures of m17-F, strains F110, F112 and F113, which do not accumulate herbicidin G, were isolated from strain

Table 4. Effect of herbicidins A, C, E, F and G on the production of herbicidins F and $\mathrm{G}$ in a growing culture of the mutant $\mathrm{m} 17-\mathrm{F}$.

\begin{tabular}{|c|c|c|c|c|c|c|c|c|}
\hline \multirow{2}{*}{ Strain } & \multirow{2}{*}{\multicolumn{2}{|c|}{$\begin{array}{l}\text { Additives } \\
(\mu \mathrm{g} / \mathrm{ml})\end{array}$}} & \multicolumn{5}{|c|}{$\begin{array}{c}\text { Potency of herbicidins }(\mu \mathrm{g} / \mathrm{ml}) \text { after } \\
70 \text {-hour incubation }\end{array}$} & \multirow{2}{*}{$\begin{array}{l}\text { Ratio of } \\
\text { bioconversion } \\
(\text { mole } \%)\end{array}$} \\
\hline & & & A & C & $\mathrm{E}$ & F & G & \\
\hline \multirow{6}{*}{$\mathrm{m} 17-\mathrm{F}$} & \multicolumn{2}{|c|}{ None } & 0 & 0 & 0 & 780 & 220 & \\
\hline & & 1,000 & 850 & 0 & 0 & 800 & 220 & 0 \\
\hline & $\mathrm{C}$ & 500 & 0 & 470 & 0 & 750 & 230 & 0 \\
\hline & $E$ & 500 & 0 & 0 & 500 & 800 & 220 & 0 \\
\hline & $\mathrm{F}$ & 1,000 & 0 & 0 & 0 & 1,750 & 230 & 0 \\
\hline & G & 1,000 & 0 & 0 & 0 & 900 & 810 & 21.5 \\
\hline
\end{tabular}


Table 5. Effect of herbicidin $\mathrm{G}$ on the production of herbicidin $\mathrm{F}$ in growing cultures of the various strains derived from $\mathrm{m} 17-\mathrm{F}$.

\begin{tabular}{ll|rrc}
\hline \multirow{2}{*}{ Strain } & $\begin{array}{c}\text { Additives } \\
(\mu \mathrm{g} / \mathrm{ml})\end{array}$ & \multicolumn{2}{|c}{$\begin{array}{c}\text { Potency }(\mu \mathrm{g} / \mathrm{ml}) \\
\text { after } 92 \text {-hour } \\
\text { incubation }\end{array}$} & $\begin{array}{c}\text { Ratio of } \\
\text { biocon- } \\
\text { version } \\
\text { (mole } \%)\end{array}$ \\
\cline { 3 - 5 } m17-F & None & F & G & \\
& G 1,000 & 1,020 & 1,140 & 19.5 \\
F110 & None & 280 & 0 & \\
& G 1,000 & 500 & 560 & 49 \\
F112 & None & 160 & 0 & \\
& G 1,000 & 370 & 450 & 38 \\
F113 & None & 240 & 0 & \\
& G 1,000 & 410 & 700 & 56 \\
\hline
\end{tabular}

Strains F110, F112 and F113 were isolated from $\mathrm{m} 17-\mathrm{F}$ by monospore isolation method and normally do not accumulate herbicidin $\mathrm{G}$ but herbicidin $\mathrm{F}$.
Fig. 1. Bioconversion of herbicidin $\mathrm{G}$ to herbicidin $\mathrm{F}$ by resting cells of strain $\mathrm{m} 17-\mathrm{F}$.

The reaction mixture was composed of $5 \mathrm{~g}$ wet weight of mycelial mass suspended in $10 \mathrm{ml}$ of $0.1 \mathrm{M}$ phosphate buffer (pH 7.0) containing $250 \mu \mathrm{g}$ of chloramphenicol and $4.5 \mathrm{mg}$ of herbicidin G. An shake-flask containing $10 \mathrm{ml}$ of the reaction mixture was shaken at $27^{\circ} \mathrm{C}$ on a reciprocal shaker.

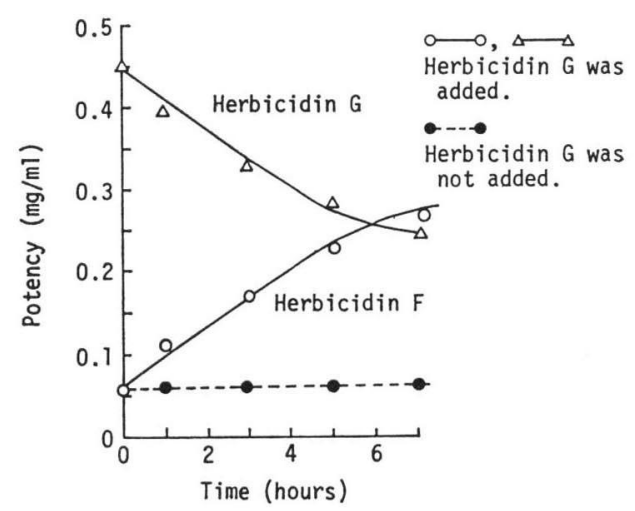

$\mathrm{m} 17-\mathrm{F}$ by the monospore isolation method. In the case of herbicidin $\mathrm{G}$ addition to growing cultures of strains F110, F112 and F113, the conversion ratio of herbicidin G to F was about 50 mole \% (Table 5).

\section{Bioconversion of Herbicidins A, F and G by Resting-cells}

Fig. 1 shows the time course of bioconversion of herbicidin $\mathrm{G}$ to $\mathrm{F}$ by resting-cells of mutant $\mathrm{m} 17-\mathrm{F}$ incubated in the presence of $25 \mu \mathrm{g}$ of chloramphenicol/ml. When herbicidin $\mathrm{G}$ was added, the concentration of herbicidin $\mathrm{F}$ increased almost linearly for about the first 5 hours, whereas the concentration of herbicidin G decreased simultaneously (Fig. 1). The conversion ratio of herbicidin $G$ to $F$ was 90 mole \%. In comparison, no herbicidin $\mathrm{F}$ was produced in the absence of herbicidin $\mathrm{G}$.

Fig. 2 shows the time course of bioconversion of herbicidins $\mathrm{F}$ and $\mathrm{G}$ to $\mathrm{A}$ by resting-cells of strain M403R under the same conditions. When herbicidin $\mathrm{F}$ was present, herbicidin $\mathrm{A}$ increased linearly for about the first 5 hours with a parallel decrease in the concentration of herbicidin $\mathrm{F}$. The conversion ratio of herbicidin $\mathrm{F}$ to A was 83 mole \% (Fig. 2-a). When herbicidin G was supplied to resting-cells, the amount of herbicidin $\mathrm{A}$ increased as a function of time during the first 5 hours of incubation concomitant with a decline in herbicidin $G$ concentration. Herbicidin $\mathrm{F}$ synthesis was also observed particularly after 3 hours as the rate of herbicidin A production decreased. The conversion ratio of herbicidin $\mathrm{G}$ to $\mathrm{F}$ was 98 mole \% (Fig. 2-b).
Fig. 2. Bioconversion of herbicidin $G$ and $F$ to herbicidin A by resting cells of strain M403R.

The reaction mixture and conditions were the same as those described in the legend to Fig. 1 except for the strain.

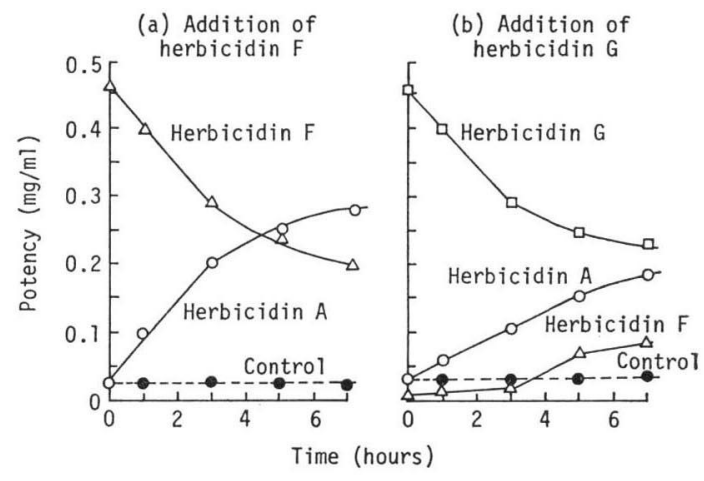




\section{Non-enzymatic Conversion of Herbicidins A, F and G}

Herbicidin $\mathrm{B}$ was formed from herbicidin $\mathrm{F}$ at $\mathrm{pH} 7.5$ and 8.5 by shaking for 30 hours. Herbicidin $\mathrm{B}$ was also formed in a herbicidin A solution under similar conditions. In both cases, the concentration of the original herbicidin decreased with the increase in herbicidin B. The conversion ratio of herbicidin F to $\mathrm{B}(29.5$ mole $\%$ at $\mathrm{pH} 7.5,18.4$ mole $\%$ at $\mathrm{pH} 8.5)$ was much lower than the conversion ratio of herbicidin A to B (44.6 mole \% at pH 7.5, 26 mole \% at pH 8.5). It was also observed that herbicidin C was formed from herbicidin $\mathrm{G}$ non-enzymatically at $\mathrm{pH} 7.5$ or 8.5. The herbicidin $\mathrm{G}$ concentration decreased simultaneously; for example, $70 \mu \mathrm{g} / \mathrm{ml}$ of herbicidin $\mathrm{C}$ were formed and the herbicidin $\mathrm{G}$ concentration decreased to $700 \mu \mathrm{g} / \mathrm{ml}$ at $\mathrm{pH} 7.5$.

\section{Discussion}

On the basis of the experimental results presented herein, it is concluded that herbicidin $\mathrm{G}$ is the intermediate employed in the biosynthesis of herbicidins A, B, C, E and F, and that it is converted to herbicidin A via herbicidin F. It appears from these data that strains M403, M403R and the mutant $\mathrm{m} 17-310$ all have the relevant enzymes to catalyze these reactions. However, mutant m17-F is blocked in a biosynthetic step between herbicidin F and A, thereby accumulating herbicidin F. The mutant $\mathrm{m} 17-\mathrm{F}$ also accumulated herbicidin $\mathrm{G}$ in the culture medium (Table 4). This finding suggests that the level of enzyme activity catalyzing the step between herbicidin $G$ and $F$, is rate limiting in contrast to the level of the enzyme activities that catalyze the biosynthesis of herbicidin $G$. The molar conversion ratio of herbicidin $G$ to $F$ was extremely low especially when herbicidin $G$ was accumulated (Tables, 4, 5). Conceivably, herbicidin $\mathrm{G}$ is converted not only to herbicidin $\mathrm{F}$ but also to some other metabolites.

Fig. 3. Proposed terminal steps in the biosynthesis of berbicidins.
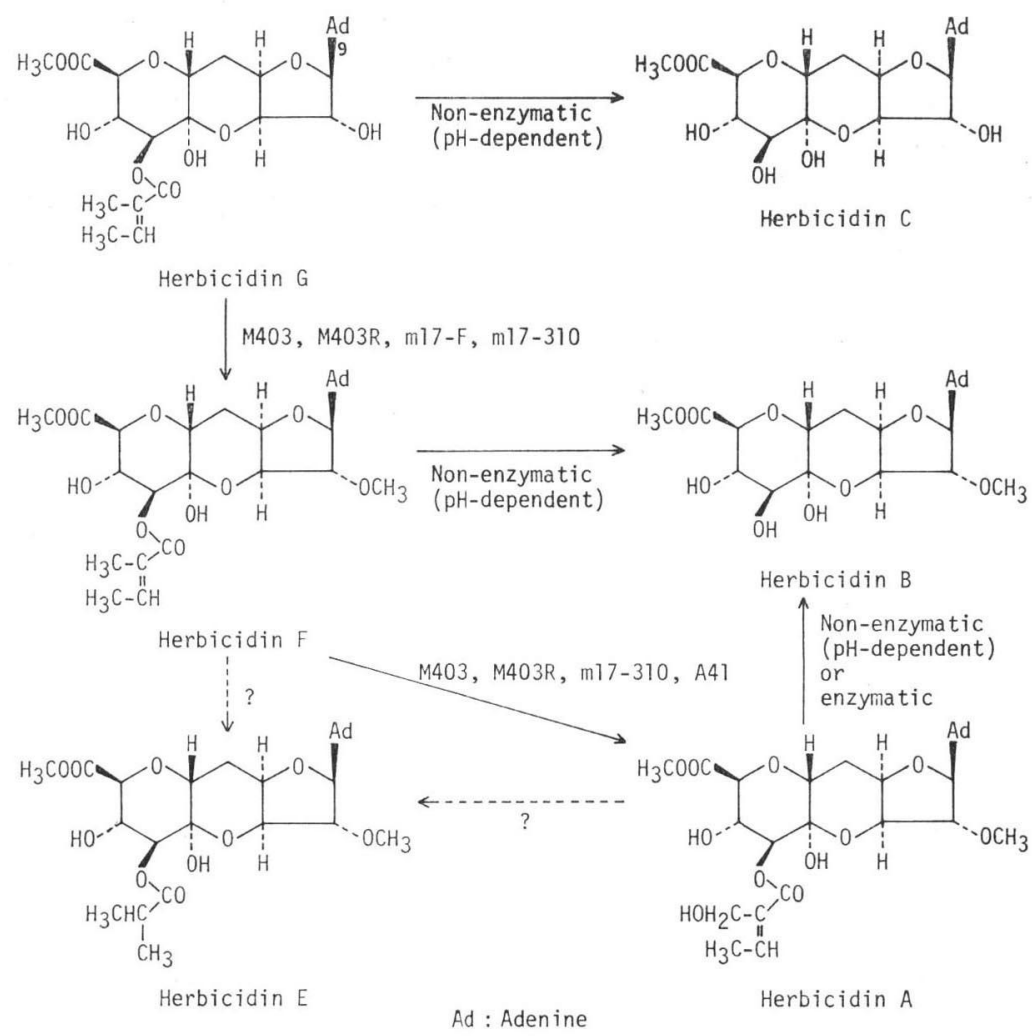
Mutant A41, which did not accumulate herbicidins but did convert herbicidin F to A, undoubtedly posesses the enzyme for the reaction. By contrast, this strain appears to lack the ability to synthesize herbicidin $F$.

In a recent report from our laboratory, it was shown that herbicidin A is converted to herbicidin B non-enzymatically ${ }^{2}$. In the present studies, we have found that herbicidin $\mathrm{F}$ is also converted to herbicidin $\mathrm{B}$, and that herbicidin $\mathrm{G}$ is converted to herbicidin $\mathrm{C}$ non-enzymatically at $\mathrm{pH} 7.5$ or 8.5. Neither herbicidin $\mathrm{C}$ nor $\mathrm{E}$ was converted to other herbicidins under the conditions used, and we were unable to obtain any mutants that were able to convert herbicidin $\mathrm{C}$ or $\mathrm{E}$. The results mentioned above suggest that herbicidin $\mathrm{C}$ and $\mathrm{E}$ are not intermediates in the biosynthetic pathway of the herbicidins.

According to all of the results mentioned above and the structures of herbicidins, elucidated by TERAHARA et al. in our laboratories ${ }^{\theta)}$, we proposed that the terminal steps in the biosynthesis of herbicidins A, B, C, E, F and G occurs as depicted in Fig. 3.

\section{References}

1) Arai, M.; T. Haneishi, N. Kitahara, R. Enokita, K. Kawakubo \& Y. Kondo: Herbicidins A and B, two new antibiotics with herbicidal activity. I. Producing organism and biological activities. J. Antibiotics 29: 863 869, 1976

2) Haneishi, T.; A. Terahara, H. Kayamori, J. Yabe \& M. Arai: Herbicidins A and B, two new antibiotics with herbicidal activity. II. Fermentation, isolation and physico-chemical characterization. J. Antibiotics 29: $870 \sim 875,1976$

3) Takiguchi, Y.; H. Yoshikawa, A. Terahara, A. Torikata \& M. Terao: Herbicidins C and E, two new nucleoside antibiotics. J. Antibiotics 32: 857 861, 1979

4) Takiguchi, Y.; H. Yoshikawa, A. Terahara, A. Torikata \& M. Terao: Herbicidins F and G, two new nucleoside antibiotics. J. Antibiotics 32: 862 867, 1979

5) Yoshikawa, H.; Y. Takiguchi \& M. Terao: Degeneration of herbicidin A-producer, Streptomyces saganonensis, and strain improvement. J. Ferment. Technol. 60: 385 391, 1982

6) Terahara, A.; T. Haneishi, M. Arai, T. Hata, H. Kuwano \& C. Tamura: The revised structure of herbicidins. J. Antibiotics 35: 1711 1715, 1982 